\title{
Evaluation of anti-pyretic activity of Plectranthus vettiveroides
}

\begin{abstract}
Plectranthus vettiveroides is widely distributed throughout the Sri Lanka. The plant is used as folk medicine in the treatment flatulence, liver disease and jaundice. The plant has bitter taste, cold potency and pungent resultant. The present study was carried out to evaluate the antipyretic potential of infusion from the root powder of Plectranthus vettiveroides. Female and male Wistar rats of with body weight 230-250g were used. Which is divided in to 3 groups, in each contains 3 animals. Rats were familiarized to laboratory conditions for four days before the commencement of experiment. Fever was induced by sub cutaneous injection of $15 \%$ Brewer's solution $(2.5 \mathrm{ml})$ in the nape of the neck. 18 hours after the giving of fever induced drug, rectal temperature was measured. Then the measurement was repeated after 30 minutes. After that infusion of root powder of Plectranthus vettiveroides $(0.5 \mathrm{ml})$ was orally administered to the test group, $0.5 \mathrm{ml}$ of normal saline $(0.9 \%)$ for control group and $0.5 \mathrm{ml}$ of Paracetamol for standard group. After animal received the test compound or the standard drug by the oral administration, the rectal temperatures were recorded again 30,60,120 and 180 minutes. Single dose administration of test drug produces significant antipyretic effect in Brewer's induced fevered rats. The root powder of Plectranthus vettiveroides showed significant reduction in the elevated body temperature of rat which was compared with standard Paracetamol. The results suggest that the infusion of leaf powder of Plectranthus vettiveroides possess antipyretic activity and can be used as potent natural antipyretic drug.
\end{abstract}

Keywords: plectranthus vettiveroides, antipyretic, brewer's solution, fever
Volume 14 Issue 3 - 202 I

Piratheepkumar R, Vijitha P

Departemnt of Siddha Medicine, Eastern University, Sri Lanka

Correspondence: Vijitha P, Department of Siddha Medicine, Trincomalee Campus, Eastern University, Sri Lanka, Tel 0772347677, Email geethan978@live.com

Received: February 01, 202I | Published: May II, 202 I

\section{Introduction}

This study is an experimental study to evaluate the anti-pyretic activity on root powder of Plectranthus vettiveroides. Elevation of the body temperature than normal level sometime increase temperature may occur in the part of the body that called "Suram". Suram may be associated with burning sensation of eye, nausea, vomiting, headache, heaviness of the head. It compare with fever in modern medicine. A fever is usually a sign that something out of the ordinary is going on in the body. For an adult, a fever may be uncomfortable, but fever usually is not dangerous unless it reaches $103^{\circ} \mathrm{F}\left(39.4^{\circ} \mathrm{C}\right)$ or higher. For very young children and infants, a slightly elevated temperature may indicate a serious infection. But the degree of fever does not necessarily indicate the seriousness of the underlying condition. A minor illness may cause a high fever, and a more serious illness may cause a low fever. ${ }^{1}$ Plectranthus vettiveroides is commonly known as Vilamichchu-ver belongs to the Lamiaceae family, In Ceylon, it is found in the warmer parts of the Island on margins of tanks. Trampaikkulam, Polonnaruwa, Ritigala. Batticaloa, Dambulla, Colombo, etc. Plectranthusvettiveroidesis useful for Antipyretic in traditional medicine, Even though the roots having anticancer and anti-oxidant potency. As per my knowledge there is no research literature till available for wound Anti-pyretic activity of root of plant form of powder. ${ }^{2}$ Researcher was explored Anti-pyretic effect of Plectranthus vettiveroides is powder on the fever model in present study, so as to provide scientific evidence for the traditional application. According to ancient traditional knowledge the plant of Plectranthus vettiveroides used for various medicinal purposes by traditional physicians but in the text book of Porutpanpu nool (Part I) by K.S.Murugesamuthaliyar mentioned the root of Plectranthus vettiveroides give for fever but there are scientific evidence so far. The current study was aimed to evaluate the antipyretic activity of root of Plectranthus vettiveroides. The following quotation mentioned the Plectranthus vettiveroides be treated for fever. Based on Porutpanpu nool (Part I) by K.S.Murugesamuthaliyar root of Plectranthus vettiveroides give for fever. Though there is no scientific evidence so far. Hence, researcher will be conducted the above study to prove it in scientific way.

\section{Literature review}

\section{Plant view}

Scientific name - Plectranthus vettiveroides (Jacob) Singh \& Sharma

\author{
Natural order - Graminale \\ English name - White cuscus grass \\ Sanskrit name - Hroeberam \\ Tamil name - vilamichu ver (Murugesamuthaliyar, 2008). \\ Parts used - root
}

The Organoleptic character is

\section{$\square$ Suwai- Bitter \\ $\square$ Thanmai-Cold \\ 7 Pirivu- Sweet}

(Murugesamuthaliyar, 2008).

\section{Gunam (Action) - Refrigerant, Anti-pitha}

A perennial herb with a branched, densely tufted rootstock with long spongy, aromatic, brown root fibres; stems $60-90 \mathrm{~cm}$ high, stout, 
erect, leafy, solid, smooth and hard and polished; leaves $30-60 \mathrm{~cm}$ long, $0.8-1.8 \mathrm{~cm}$ broad, sub-bifarous, erect, narrowly linear, firmly acuminate, flat, strongly keeled towards the base, smooth, margins usually scaberulous, sheaths coriaceous, glabrous, not auricled, ligule a ridge of minute hairs; panicle $10-30 \mathrm{~cm}$ long, erect, narrowly thyrsiform, of fascicled, suberect, slender,' articulate spikes, $5-7.5 \mathrm{~cm}$ long, spikelets in alternate pairs, a sessile bisexual and a pedicelled male; sessile spikelet 1 -flowered, $0.4 \mathrm{~cm}$ long, glumes 4, palea ovatelanceolate; lodicules very minute, broadly quadrate, many-veined, connate; stamens 3 , hypogynous, one at the base of the flowering glume, one opposite each vein of the palea, filaments capillary, anthers of two parallel cells; ovary superior, unilocular with a basal erect ovule, style and stigmas short; pedicelled spikelet oblong-lanceolate, pedicel as long as the internode, tip bearded; glumes 4, palea linearoblong, obtuse; lodicules cuneate, anthers linear. ${ }^{2}$

It occurs in India, Ceylon, Burma, Malaya and tropical Africa. It is cultivated in the Philippines. In Ceylon, it is found in the warmer parts of the Island on margins of tanks. Trampaikkulam, Polonnaruwa, Ritigala. Batticaloa, Dambulla, Colombo, etc. The oil distilled from the roots of this plant contains vetivenens, vetivenol, vetivenic acid, vetivenyl acetate and similar compounds. ${ }^{2}$

The root acts as a bitter stomachic, carminative and cholagogue and as such is useful in anorexia, chronic dyspepsia, flatulence, acute and chronic congestion of the liver and jaundice. Its value is attributed to its eliminative powers as a diaphoretic, diuretic and cholagogue. It is often employed as an antiperiodic in malarial fevers. ${ }^{2}$

In Ceylon, it is used for preparations in the treatment of typhoid fever, hemoptysis, phthisis, anemia, skin and blood diseases, urinary disorders, piles, edema, etc. The bruised roots mixed with milk are. Often applied on the head for congestive headache for the delirium Caused by typhoid, pneumonia and meningitis. The dried roots are used for scenting clothes, for making fans and mats. The oil contains $\wedge$ considerable quantities of high grade perfumes. ${ }^{3}$

The objective of the study was to identify the effectiveness of Plectranthus vettiveroides root powder in anti-pyretic activity on animal.

\section{Materials and methods}

\section{Plant material}

This plant Vilamichchu-ver was selected through quotation of general character of plant from the book, Siddha material medica (plant division) part-01 by Dr. K.S. Murugesamuthaliyar, Page no818. Root of Plectranthus vettiveroides were collected from the shop, which situated in Trincomalee town. Plant Plectranthus vettiveroides (vilamichu ver) was authenticated by supervisor. ${ }^{4-11}$

\section{Preparation of drug}

Plectranthus vettiveroides root was collected. Then dried in shade and chopped well. Then prepared fine powder and stored (room temperature) in airtight bottles for further use.

\section{Dose determination}

The dose of the infusion was determined according to common scale with the guidance of supervisor. The dose of the test formulation was calculated by generalizing the human dose to animals based on the body surface area ratio by referring to the common scale. The study was carried out using single dose level, i.e., the therapeutically the tested drug is $(3 \mathrm{~g} / 60 \mathrm{~kg})$.

\section{Animal study}

Male \& Female Wister rats of weighing 230-250g were procured from University of Peradeniya animal house for experimental study. Female and Male Wistar rats were used for the experiment. The animals were kept in a clean and dry cages with suitable light in laboratory in normal temperature with relative humidity for one week before the commencement of experiments, and were allowed free admission to standard pellet diet and water. According to the common scale and guidance of supervisor the single dose of $3 \mathrm{~g}$ for $60 \mathrm{~kg}$ for body weight of human and infusion made by $1 \mathrm{~g}$ for $10 \mathrm{ml}$ for human this dose based on body surface area of Wistar rats. The weighed $3 g$ of fine powder of Vilamichau ver was soaked in to $30 \mathrm{ml}$ of boiled cool water for overnight and filtered by clean cloth.

\section{Preparation of standard drug}

The single dose of standard Paracetomol is $3.34 \mathrm{mg} / 200 \mathrm{~g}(1 \mathrm{~g} / 60 \mathrm{~kg})$ in $0.1 \mathrm{ml}$ according to the body weight. The $15 \%(\mathrm{w} / \mathrm{v})$ suspension of Brewer's yeast solution was prepared weighed $7.5 \mathrm{~g}$ and it was mixed with $50 \mathrm{ml}$ of $0.9 \%$ saline. To use as a dose for induced fever $10 \mathrm{ml} / \mathrm{kg}$ $(2 \mathrm{ml} / 200 \mathrm{~g})(15 \mathrm{~g}$ yeast mixed with $100 \mathrm{ml}$ of water).

The subcutaneous injection of Brewer's yeast suspension (15\% of yeast, $0.9 \%$ saline is used) is known to produce fever in rats. The increase temperature can be achieved by administration of compounds with pyretic activity. Male \&Female Wister rats of with body weight 230-250gwere used. Which is divided in to 3 groups (control, test and standard) each group compromising with 4 rats and cages with Wistar rats were labeled. The first group served as control for received with distilled water $(0.1 \mathrm{ml} / 200 \mathrm{~g})$.

The second group for administration with Paracetamol $(3.34 \mathrm{mg} / 200 \mathrm{~g})$ as the standard drug. The third group was issued with tested drug $(0.01 \mathrm{~g} / 200 \mathrm{~g})$. This test was carried out at laboratory in normal temperature. By insertion of thermo couple in the depth of $2 \mathrm{~cm}$ in the rectum the initial rectal temperature was recorded. Before it the animals are fevered by injection of $10 \mathrm{ml} / \mathrm{kg}(2 \mathrm{ml} / 200 \mathrm{~g})$ of brewer's suspension subcutaneously in the back below the nape of the neck of wistar rats then immediately massaged on injected area for suspension is spread beneath the skin. Immediately after yeast administration the food is withdrawn. 18 hours post challenge, the raise in rectal temperature was recorded. The measurement was repeated after 30 minutes. Only animals with the body temperature of at least $38^{\circ} \mathrm{c}$ are taken into the test. After animal received the test compound or the standard drug by the oral administration, the rectal temperatures were recorded again 30,60,120 and 180 minutes.

The differences between the actual value and the starting values were registered for each time intervals. The maximum reduction of temperature to the test group is calculated. The results were compared with the effect of standard drug.

\section{Result and discussion (Tables I-2)}

In test group significantly decreased the induced elevated body temperature as compared to control group. The sudden reduction of temperature was observed from $1 / 2$ hour to 1 hour period after administration of test drug. The maximum antipyretic activity by Paracetamol as a standard drug was observed within 1 hour period. After the 1 hour, administration of test drugs shows markedly reduction in elevated body temperature in rats compared to control. The results indicate the test drug less equal to standard drug (Figures 1-4). 
Table I Reading of rectal temperature with time interval before induce and after

\begin{tabular}{lllllll}
\hline Control & Base line & $\mathbf{6 . 0 0}$ a.m & $\mathbf{6 . 3 0}$ a.m & $\mathbf{7 . 0 0}$ a.m & $\mathbf{7 . 3 0}$ a.m & $\mathbf{8 . 0 0}$ a.m \\
\hline RI & 36.8 & 38.2 & 38.2 & 38.0 & 38.1 & 38.0 \\
R2 & 36.9 & 37.9 & 37.9 & 38.0 & 37.9 & 37.9 \\
R3 & 36.8 & 37.8 & 37.9 & 37.9 & 37.8 & 37.9 \\
R4 & 36.8 & 38.0 & 38.0 & 38.1 & 38.1 & 38.0 \\
Test & & & & & & \\
R5 & 36.7 & 38.1 & 38.0 & 37.9 & 37.5 & 37.0 \\
R6 & 36.8 & 38.2 & 38.0 & 38.0 & 37.3 & 36.9 \\
R7 & 37.0 & 38.1 & 38.1 & 37.6 & 37.4 & 36.9 \\
R8 & 36.9 & 38.2 & 38.1 & 38.0 & 37.4 & 37.0 \\
Standard & & & & & & 37.9 \\
R9 & 36.8 & 38.2 & 38.0 & 37.9 & 37.5 & 36.8 \\
RI0 & 36.8 & 38.1 & 38.0 & 37.8 & 37.4 & 36.8 \\
RII & 37.0 & 38.0 & 37.9 & 37.8 & 37.3 & 36.8 \\
RI2 & 37.1 & 37.9 & 37.8 & 37.7 & 37.2 & 36.9 \\
\hline
\end{tabular}

Table 2 Average rectal temperature of all three groups with the time

\begin{tabular}{lllllll}
\hline \multicolumn{7}{c}{ After 18 hours } \\
Group & $\begin{array}{l}\text { Initial } \\
\text { reading }\end{array}$ & $\begin{array}{l}\mathbf{6 . 0 0} \mathbf{a m} \text { (drug } \\
\text { give) }\end{array}$ & $\mathbf{6 . 3 0 \mathrm { am }}$ & $\mathbf{7 . 0 0 \mathrm { am }}$ & $\mathbf{7 . 3 0 \mathrm { am }}$ & $\mathbf{8 . 0 0 \mathrm { am }}$ \\
\hline Control & 37.93 & 37.97 & 38 & 38 & 37.97 & 37.95 \\
Standard & 37.96 & 38.05 & 37.92 & 37.8 & 37.35 & 36.8 \\
Test & 38.00 & 38.15 & 38.05 & 37.87 & 37.4 & 36.95 \\
\hline
\end{tabular}

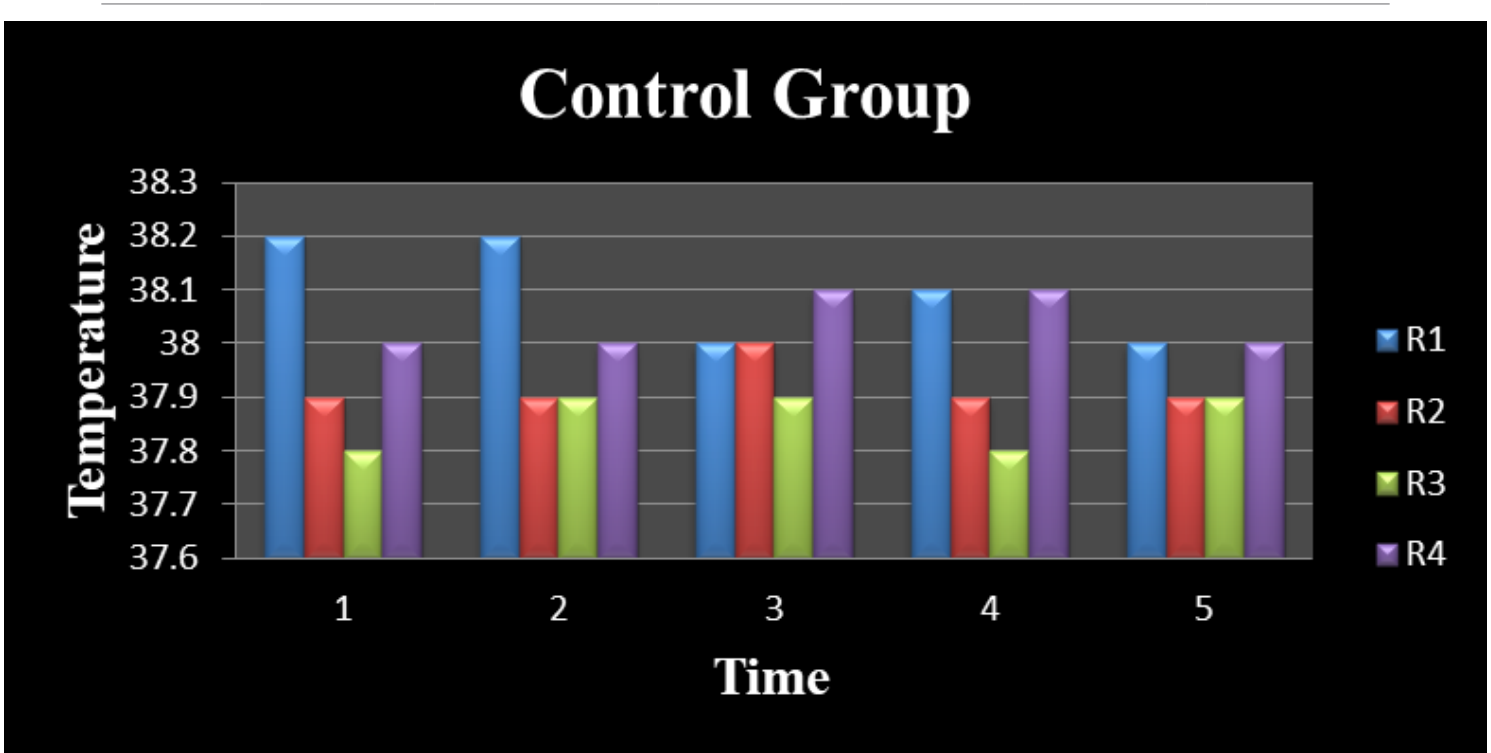

Figure I Pattern of the temperature reduction of control group with time.

Citation: Piratheepkumar R,Vijitha P. Evaluation of anti-pyretic activity of Plectranthus vettiveroides. Int J Complement Alt Med. 202 I; I4(3): I07-I I I. DOI: 10.15406/ijcam.2021.14.00542 


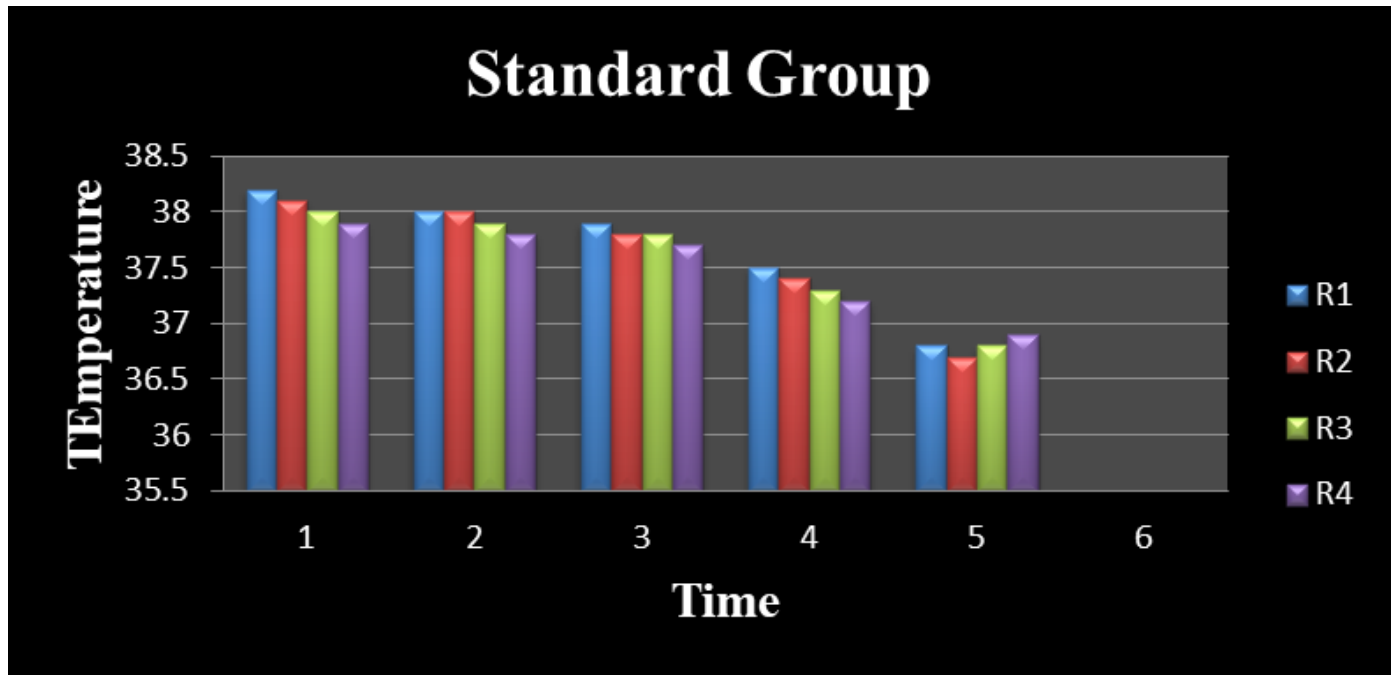

Figure 2 Pattern of the temperature reduction of standard group with time.

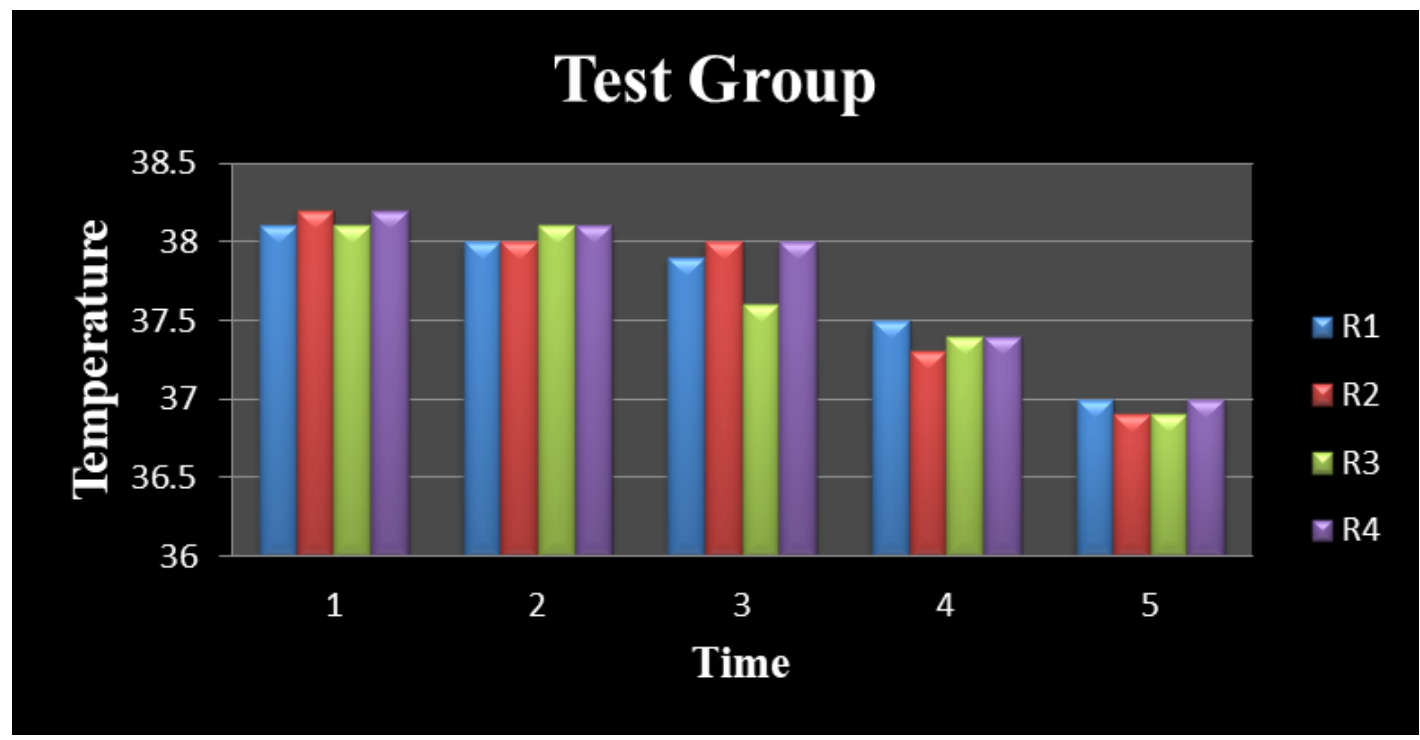

Figure 3 Pattern of the temperature reduction of Test group with time.

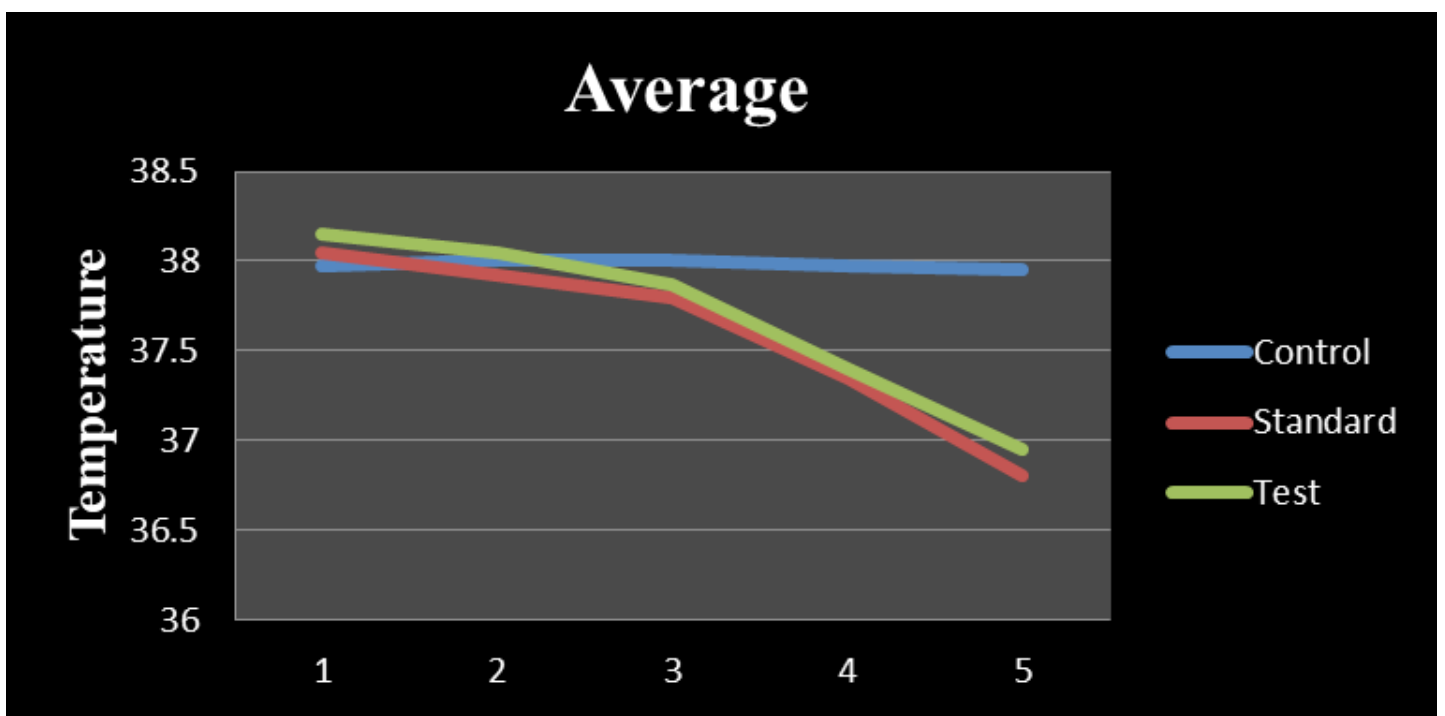

Figure 4 Average temperature decline with the time.

Citation: Piratheepkumar R,Vijitha P. Evaluation of anti-pyretic activity of Plectranthus vettiveroides. Int J Complement Alt Med. 202 I; I4(3): I 07-I I I. DOI: 10.15406/ijcam.202I.14.00542 


\section{Discussion}

As per siddha literature of Kunapadam Moolihaivahuppu Muthatpaakam, Porutpanpu nool, Plectranthus vettiveroides root powder were mentioned for fever and it was made to do the above scientific studies. To cure the fever-the antipyretic action is playing a major role to treat the fever. Therefore the researcher did the above scientific study. Fever is usually a sign that something out the ordinary is going on in the body. But in siddha medicine it is a disease. For an adult, a fever may be uncomfortable, but fever usually is not dangerous unless it reaches $103^{\circ} \mathrm{F}\left(39.4^{\circ} \mathrm{C}\right)$ or higher. For very young children and infants, a slightly elevated temperature may indicate a serious infection. But the degree of fever does not necessarily indicate the seriousness of the underlying condition. A minor illness may cause a high fever, and a more serious illness may cause a low fever. Oral temperature in cohort ranged from $35.6^{\circ} \mathrm{C}\left(96.0^{\circ} \mathrm{F}\right)$ to $38.5^{\circ} \mathrm{C}\left(100.8^{0} \mathrm{~F}\right)$ with a mean of $36.8 \pm 0.4^{\circ} \mathrm{C}\left(98.2 \pm 0.7^{\circ} \mathrm{F}\right)$. Rectal temperature are generally $0.6^{\circ} \mathrm{C}\left(1.0^{\circ} \mathrm{F}\right)$ higher than oral readings. The normal daily temperature variation is typically $0.5^{\circ} \mathrm{C}\left(0.9^{\circ} \mathrm{F}\right)$

Effectivenessisexplainedonthebasis ofRasa, Veeriya, Vipaka, action and properties of selected plant. According to Siddha, derangement of Pitha causing fever. The plant Plectranthusvettiveroides has the properties of bitter taste, cold potency, and sweet resultant. The plant is seethaveeriyam and sweett vipakam. Seetha Veerya which helps in pacification of aggravated Pitha, and reduced the body temperarure. Sweet resultant also helps in pacify th e pitham and made the body temperature to normal level. Suram reduced under the condition of cold potency and sweett resultant of this plant. Above explanations has been supported by the results obtained from this study.

\section{Conclusion}

The Plectranthus vettiveroides root infusion showed marked antipyretic activity compared to control group. Through the result the quotation which was mentioned in the Porutpanpu nool (part 1) about Plectranthus vettiveroides was proven by the experimental study.

\section{Acknowledgments}

None.

\section{Conflicts of interest}

Author declares that there are no conflicts of interest.

\section{Funding}

None.

\section{References}

1. Axelrod YK, Diringer MN. Temperature management in acute neurologic disorders. Neurol Clin. 2008;26 (2):585-603.

2. Jayaweera D. Medicinal plants used in Ceylon. Part II. India, New Delhi; Business Horizons Pharmaceutical Publishers; 2002. pp.29.

3. Murugesamuthaliyar K. Siddha material medica (meditional plant division), 1st edn. India, Chennai: Inthiya maruthuvam, homeopathithurai; 2013. pp.265-266.

4. Hisham A, Padmaja V, Sivakumar N, et al. Composition and antimicrobial activity of essential oil of Plectranthus vettiveroides. Current Topics in Phytochemistry. 2012;11(2012):59-65.

5. Balasankar1 D, Vanilarasu K, Selva Preetha R, et al. Traditional and Medicinal Uses of Vetiver. Journal of Medicinal Plants Studies. 2013;1(3):191-200.

6. Central Drug Research Institute. Lucknow: Publications and information directorate; 1993. pp. 265-266.

7. Kumar P, Clark M. Essentials of Kumar \& Clark's Clinical Medicine. 5th edn. USA: Saunders Elsevier; 2011. pp. 13-14.

8. Nisheeda BA, Safeer S, Sreekumar CK, et al. A review on Plectranthus vettiveroides: an endemic to South Indian high value aromatic medicinal plant. IOSR Journal of Pharmacy and Biological Sciences. 2016;11(2):111.

9. Safee M, Sreekumar S, Krishnan N, et al. Influence of stem cuttings, spacing, group planting, light, irrigation and harvesting period on yield in Plectranthus vettiveroides. IOSR Journal of Agriculture and Veterinary Science. 2013;6(3):47-53.

10. Shanmugavelu M. Noi nadal noi muthal nadal thirattu part-2. India, Chennai: Directorate of Indian Medicine \& Homeopathy; 2003.

11. Sundara Ganapathy R, Mohan S, Kameshwaran S, et al. Effect of BioFertilizers on Growth and Biomass of Coleus Vettiveroides In vitro Anti-cancer and in vitro anti-oxidant potency of roots of hydro Alcoholic extract of Plectranthus vettiveroides. IOSR Journal of Pharmacy and Biological Sciences. 2015;3(1). 